\title{
Risk factors for basal cell carcinoma: a case-control study*
}

\author{
Marcus Maia, Nelson Guimarães Proença, José Cássio de Moraes \\ Departments of Medicine and Social Medicine of "Faculdade de Ciências \\ Médicas da Santa Casa de São Paulo" - Brazil
}

\begin{abstract}
A controlled trial was performed with the purpose of investigating which factors could be considered of significant risk for the development of basal cell carcinoma. A total of 259 cases of basal cell carcinoma diagnosed from July 1991 to July 1992 were compared with 518 controls matched for age and sex. All subjects in both groups were white. Protocol data were submitted to statistical analysis by the chi-square test and by multiple conditional logistic regression analysis and the following conclusions were reached: 1) light skin color (types I and II of the Fitzpatrick classification), odds ratio of 2.8; outdoor work under constant sunlight, odds ratio of 5.0; the presence of actinic lesions due to exposure to the sun, odds ratio of 4.9, are risk factors per se. 2) Type Ill skin in the Fitzpatrlck classification only represents a risk factor when the patient reports a history of intense sunburns, but not In the absence of such a history. 3) Sunburns per se do not represent a risk factor althorig the point made in Item 2 of these conclusions is valid. 4) Other suspected risk factors whose significance was not confirmed by multiple conditioned logistic regression analysis were: residence in rural areas, light eyes and blond hair color, extent of the awareness of the "sun $x$ skin cancer" relationship, familial occurrence of skin cancer, excessive exposure to the sun, and freckles appearing in childhood.
\end{abstract}

Carcinoma, basal cell, epidemiology.Risk factors.

\section{Introduction}

Basal cell carcinoma (BCC) is the most common cancer occurring in human beings, but is one of the least studied types of cancer ${ }^{17}$. In 1988 , more than 400,000 cases of BCC were diagnosed in the USA ${ }^{32}$, as opposed to 980,000 cases diagnosed for all other types of cancer together. In the Rochester region, (USA), Chuang et al. $^{7}$ detected a prevalence of 146 cases per 100,000 inhabitants, while the prevalence estimated in Australia was 1,335 per 100,000 inhabitants for men and 817 per 100,000 inhabitants for women ${ }^{2 !}$.

The latest survey made in Brazil by the National Tumor Registration Program**, corresponding to the years 1981 to 1985 , reports 139,407 skin cancers, 99,176 of which were BCC. Thus, there seems to be an approximate annual mean of about 20,000 new recorded $\mathrm{BCC}$ cases for Brazil as a whole. Although these numbers do not give the complete picture (only the cases submitted to anatomopathological examination were computed), this occurrence is still almost twice that of cancer of the cervix, the second most frequent type of cancer in Brazil.

Even though available data on the occurrence of BCC do not give the full picture, they are still a source of great concern, especially because of the increased incidence of $\mathrm{BCC}$ in the white population over the last twenty years ${ }^{33}$. In addition, there is the growing threat represented by the degradation of the ozone layer ${ }^{30,33}$.

Information about the epidemiology of $\mathrm{BCC}$ and, more appropriately, about the risk factors for its occurrence will permit the organization of preventive and individual orientation campaigns.

Few studies are available on the risk factors for $\mathrm{BCC}^{15,18,34}$. Since the risk factors for the development of $\mathrm{BCC}$ are related not only to genetic (constitutional) characteristics but also to environmental aspects, it may be assumed

\footnotetext{
"Part of the Doctoral Thesis presented at the "Escola Paulista de Medicina", I993, by Marcus Maia

**Umpublished

Reprints: Marcos Maia - Rua Turiaçu, 143 - Conj. 123 - 05005.00I - S. Paulo, SP - Brazil

The publication of this article was supported by FAPESP. (Process 94/0500-0).

Submited in 3.11.1994. Approved in 11.21.1994.
} 
that differences will occur between populations and between ecological conditions.

From the viewpoint of living conditions in Brazil, especially in the Southeast region of the Country, what are the risk factors which determine the frequency of $\mathrm{BCC}$ ? A survey of the Brazilian medical literature does not reveal any study dealing specifically wich this subject. Thus, sicks to determine the significant (genetic and environmental) risk factors which contribute to the development of BCC in the population investigated.

\section{Cases and Methods}

The present study was carried out in the Sector of Dermatologic Surgery and Oncology, Dermatology Clinic, "Santa Casa de S. Paulo", Brazil, which characteristically deals with indigent patients. A protocol for the study of BCC was elaborated and introduced on July 28,1991 . Since the objective was to study the risk factors in patients with $\mathrm{BCC}$ seen and diagnosed at the Dermatology Clinic, it was considered necessary to form a simultaneous control group also observed by means of using a specific protocol.

\section{Clinical Material}

The study was of the case-control type and was carried out from July 28,1991 to July 28,1992 . A total of 259 consecutive patients with a histopathologically confirmed diagnosis of BCC were examined and submitted to the protocol. These patients had spontaneously sought the Dermatology Clinic and, by coincidence, all of them were whites. For the purposes of the present study, the following patients with $\mathrm{BCC}$ were excluded: (a) patients having uncommon clinical conditions predisposing them to the development of BCC, i.e., basal cell nevus syndrome, xeroderma pigmentosum, albinism, and Basex syndrome; (b) patients with $\mathrm{BCC}$ originating from hamartomas such as sebaceous nevus, unilateral basal cell linear nevus, and Balzer type sebaceous adenoma (trichoepithelioma); (c) patients with $\mathrm{BCC}$ originating from chronic radiodermitis; (d) patients submitted to a chronic state of immunodepression; (e) patients with chronic arsenicism.

\section{Protocol for Patients with Basal Cell Carcicoma}

The following data were collected by means of the protocol:

a) identification: name, age at diagnosis, birth date, sex, date of diagnosis.

b) Medical history data related to basal cell carcinoma: occupation, birthplace (urban or rural), residence (urban or rural) and respective times of residence, exposure to the sun during life (mild, moderate or intense), previous sunburns, freckles during childhood, family history of skin cancer, information about the relationship between exposure to the sun and skin cancer.

c) racial characterization; skin color (white, brown, yellow, or black), original hair color (blond, auburn, brown, black), eye color (blue, green or brown), skin type (phototype) according to the classification of Fitzpatrick ${ }^{10}$ : type I (always gets burned, never tans), type II (always gets burned, tans slightly), type III (rarely gets burned, tans moderately), type IV (never gets burned, tans easily), type V (never gets burned, tans intensely), and type VI (black race).

d) associated clinical lesions attributable to solar radiation (chronic exposure): solar keratosis of the face, freckles on the back of the hand, facial telangiectasia, neck elastosis. No scores were used to characterize the intensity of these alterations.

\section{Protocol for the Case-Contro 1 Groups}

The control group consisted of a sequence of new patients who spontaneously sought the Dermatology Clinic at the same time as the BCC cases were seen but who did not present skin cancer. It was possible to organize a control group of 518 persons. All patients in the control group were also whites and were rigorously matched ( 2 controls for each BCC case) to the patients for sex and age (same year of birth).

There were no other exclusion criteria. The data collected were the same as for the $\mathrm{BCC}$ group, including type of skin (phototype) according to the classification proposed by Fitzpatrick $^{10}$.

\section{Statistical Analysis}

The suspected risk factors studied in BCC cases and controls were transformed into dichotomous variables and denoted $x_{1}, x_{2}, \ldots, x_{r}$, 
with the "zero" value being attributed to the possible absence of a risk factor and the "one" value to the possible presence of a risk factor. The risk factors studied were those normally cited in the medical literature as important for the development of $\mathrm{BCC}$.

The suspected risk factors (variables), i.e., previous or present agricultural activity, previous or present residence in the rural zone, intense exposure to the sun throughout life, history of intense sunburn(s), freckles in childhood, a family history of skin cancer, patient's awareness of the sun $x$ skin cancer relationship, were qualitatively coded as "yes" (presence of the risk factor, "one" value) or no (absence of the risk factor, "zero" value).

For the skin type variable (phototype) classified according to Fitzpatrick ${ }^{10}$, skin $\mathrm{I} / \mathrm{II}$ and skin III with a history of sunburn were considered as a risk factor ("one" value); skin IV/V and skin III with no history of sunburn, were considered of no risk ("zero" value). Thus, type III skin was considered to be a risk factor or not according to the presence or absence of a previous history of burns resulting from exposure to the sun. Type VI skin was excluded because no patient with BCC had black skin.

In this classification, light eyes (blue or green) and light hair (auburn or blond) were considered to be risk factors ("one" value).

The variable "skin changes attributable to chronic solar radiation" (solar keratosis of the face, freckles on the back of the hands, facial telangiectasia, and skin elastosis) was considered to be a risk factor in the presence of three or four alterations ("one" value), and was not considered to be a risk factor in the presence of two or fewer alterations ("zero" value).

The relative frequency of risk factors among cases who were found to differ significantly from the control by the chi-square test was analyzed by multiple conditional logistic regression using the backward model. Values of $p<0.05$ were considered to be significant for both tests.

The calculations were performed using the MULTLR software ${ }^{6}$. Thus, a model of multiple conditional logistic regression was constructed using the risk factors found, by regression analysis to be significant.

\section{Results}

\section{Risk Factors for Basal Cell Carcinoma (a Case- Control Study)}

The results concerning suspected risk factors (type of skin, skin changes produced by solar radiation, intense exposure to the sun, residence in the rural area, unawareness of the fact that excess exposure to the sun may cause skin cancer, agricultural activity, green or blue eye color, freckles in childhood, blond or auburn hair color, family history of skin cancer) were present at significantly higher frequency in the case group than in the control group (chisquare test) except for history of sunburn $(p>0.05)$ (Table 1).

When the risk factors were analyzed by multiple conditional logistic regression, only three variables (skin changes attributable to solar radiation, agricultural activity, and skin type) continued to be significant (Table 2). The three variables were adjusted to one another and the final model of multiple conditional logistic regression is presented in Table 3: agricultural activity (odds ratio, 4.9), skin

Table 1. Risk factors for basal cell carcinoma (BCC) detemined in a case-control study. Dermatology Clinic of "Santa Casa de S. Paulo" (1991-1992).

\begin{tabular}{|c|c|c|c|}
\hline Rlsk factors & $\% \mathrm{CBC}$ & $\%$ Control & $P$ value ${ }^{1}$ \\
\hline \multicolumn{4}{|l|}{$\begin{array}{l}\text { I/I or III skin type } \\
\text { with a history }\end{array}$} \\
\hline $\begin{array}{l}\text { of sunburn(s) } \\
\text { Skin changes produced } \\
\text { by solar radiation }\end{array}$ & 34.0 & 21.4 & $<0.0005$ \\
\hline $\begin{array}{l}\text { (three or more) } \\
\text { Intense exposure to }\end{array}$ & 71.8 & 34.4 & $<0.0005$ \\
\hline $\begin{array}{l}\text { the sun throughout llfe } \\
\text { Residence In }\end{array}$ & 66.4 & 35.9 & $<0.0005$ \\
\hline $\begin{array}{l}\text { the rurel area } \\
\text { Unawareness that } \\
\text { excess exposure } \\
\text { to the sun may cause }\end{array}$ & 59.1 & 41.9 & $<0.0005$ \\
\hline skin cancer & 51.0 & 40.3 & $<0.005$ \\
\hline $\begin{array}{l}\text { Agricultural activity } \\
\text { Green or blue }\end{array}$ & 44.0 & 16.2 & $<0.0005$ \\
\hline eye color & 40.5 & 22,8 & $<0.0005$ \\
\hline $\begin{array}{l}\text { Freckles in childhood } \\
\text { Blond or auburn }\end{array}$ & 30.1 & 16.8 & $<0.0005$ \\
\hline $\begin{array}{l}\text { hair color1 } \\
\text { Family history }\end{array}$ & 8.9 & 10.0 & $<0.005$ \\
\hline $\begin{array}{l}\text { of skin cancer } \\
\text { A history of }\end{array}$ & 14.3 & 7.7 & $<0.05$ \\
\hline intense sunburn(s) & 23.2 & 27.8 & $>0.05$ \\
\hline
\end{tabular}

${ }^{1}$ Chi-square test 
changes attributable to solar radiation (odds ratio, 5.0), and skin type (odds ratio, 2.8).

Once it had been determined by the statistical methods applied that the risk variables were in fact three, it was possible to construct the logarithmic equation that expressed the logistic disease model, i.e., the equation for BCC:

Logistic disease model:

$$
1,5938 \cdot x_{1}+1,6041 \cdot x_{2}+1,0208 \cdot x_{3}
$$

where $x_{1}$ represents agricultural activity; it should be kept in mind that in a given patient the value of $x_{1}$ will be one or zero, according to the presence or absence of this activity.

$\mathrm{x}_{2}$ represents actinic changes of the skin; it should be kept in mind that the presence of two or less of the four changes studied represents the zero value, and the presence of three or more of them represents the one value.

$\mathrm{x}_{3}$ represents the skin type in the classification of Fitzpatrick ${ }^{10}$; it should be kept in mind that the one value was attributed to skin I and II and the zero value was attributed to skin IV and V; type III skin was considered to be zero when there was no history of sunburn(s) and one when this history was present.

Tabje 2. Multiple conditional logistic regression analysis of risk factors for basal cell carcinoma. Dermatology Clinic, "Santa Casa de S. Paulo".

\begin{tabular}{cccc}
\hline $\begin{array}{c}\text { Risk } \\
\text { factors }\end{array}$ & $\begin{array}{c}\text { Odds } \\
\text { ratio }\end{array}$ & $\begin{array}{c}95 \% \text { Confldence } \\
\text { interval } \\
\text { Odds ratio }\end{array}$ & $\begin{array}{c}P \\
\text { value }\end{array}$ \\
\hline
\end{tabular}

Skin changes

produced

by solar radiation

Agricultural activity

I/II or III skin type

with a history

of sunburn(s)

Freckles in

childhood

intense exposure

to the sun

Green or blue

eye color

Famlly hlstory

of skin cancer

Unawareness

that excess

exposure to the sun

may cause skin

cancer

Blond or auburn

hair color

Residence in

the rural area
$3.2-7.8$

0,0000

0,0000

0,0001

0,0873

0,1102

0,3339

0,4824

$0.6 \cdot 1.7$

0,9336

\section{Discussion}

The characteristics of individuals predisposed to skin cancer have been frequently cited in the literature, but the conclusions have been mainly based on clinical observations and on studies not submitted to an adequate methodology for the identification of risk factors ${ }^{9,14,20}$.

We would like to emphasize four studies in the international literature that will be discussed in detail here: in 1965 , Gellin et al. ${ }^{11}$ carried out a controlled study to determine the factors associated with BCC and showed that there is a statistically significant tendency to the development of BCC in patients with light-colored eyes, with light hair, with light skin, who do not tan, who spend many hours exposed to the sun. However, only $6 \%$ of the $\mathrm{BCC}$ cases had all of these five characteristics (in contrast to $0.6 \%$ of the controls). The data were analyzed by the chi-square test. However, even though they emphasized the small number of BCC cases having all the characteristics considered to be significant, the authors could not use more refined methods for a better explanation of this fact because such methods were not available at the time.

Vitaliano and Urbach ${ }^{34}$ in the USA, and Green and Battistutta ${ }^{15}$, in Australia, conducted studies of the risk factors by applying multiple conditional logistic regression analysis, which is a more adequate statistical model. Their studies referred to non-melanoma skin cancer in general and their results regarding $\mathrm{BCC}$ will be discussed below.

In the review undertaken by the authors of the present paper, Hogan et al. ${ }^{18}$ were the only investigators who conducted a controlled study specifically for BCC. They also applied multiple conditional logistic regression analysis which permitted them to compute the relative risk factors. This method identified in a more appropriate manner individuals at high risk of developing $\mathrm{BCC}$.

The results of these studies have been summarized in Table 4 . Note that only the risk factors studied by the present authors have been included in the Table 4. For example, Hogan et al. ${ }^{18}$ studied Irish, Scottish and Welsh descent of the parents as a risk factor. Since this 
Table 3. Final model of multiple conditional logistic regression for risk factors for basal cell carcinoma. Dermatology Clinic, "Santa Casa de S. Paulo" (1991-1992).

\begin{tabular}{lllcc}
$\begin{array}{c}\text { Risk } \\
\text { factors }\end{array}$ & $\begin{array}{c}\text { Logistic } \\
\text { regression } \\
\text { coefflcient }\end{array}$ & $\begin{array}{c}\text { Odós } \\
\text { ratio }\end{array}$ & $\begin{array}{c}95 \% \text { Confidence } \\
\text { interval } \\
\text { Odds ratio }\end{array}$ & $\begin{array}{c}P \\
\text { value }\end{array}$ \\
\hline Agricultural & 1,5938 & 4.9 & $3.2 \cdot 7.6$ & 0,0000 \\
activity & 1,6041 & 5.0 & $3.2 \cdot 7.8$ & 0,0000 \\
Skin changes & 1,0208 & 2.8 & $1.8 \cdot 4.2$ & 0,0000 \\
Skin type & & & &
\end{tabular}

characteristic has not been studied in this project it has been excluded from Table 4.

The papers published in Brazil about BCC epidemiology are generally retrospective and descriptive $2,4,29,31$. Even prospective studies ${ }^{12,27,28}$ were also descriptive, a fact that prevents the application of statistical methods for evaluation of the results. Even though the data collected in these studies cannot be compared with those of the present study, they will also be discussed, at least, in a generic manner.

The present study detected differences in the relative importance of suspected risk factors quoted out in the literature and these data will be discussed on the basis of the principles governing the study of risk factors for a given disease, i.e.: 1) there must be biological plausibility; 2 ) the factors must precede the onset of the disease.

Each of the factors studied will then be discussed individually, indicating when they were significant or not and the results will then be compared with data from the literature.

From a purely observational viewpoint, the controls belonged to the same population group that produced the cases, i.e., they were persons who spontaneously sought the hospital (which is a reference hospital), who in general belonged to the same socioeconomic group and who were excluded only on the basis of the criterion of having or having had skin cancer.

\section{Nonsignificant Risk Factors}

In the present study, only one of the probable suspected risk factors was similarly distributed between cases and controls $(p>0.05$ ), i.e., the occurrence of previous intense sunburn(s) reported by the patient (Table 1 ). This fact was expected and is consistent with the findings ${ }^{15,24,26}$ registered in the literature demonstrating that sunburn is a risk factor for malignant melanoma but not for non-melanoma cancer. In a previous investigation in which they studied the sunburns of their patients quantitatively, Green et al. ${ }^{16}$ were only able to detect a discrete significance for non-melanoma skin cancer when the number of reported sunburns was of more than six episodes during the patient's life.

The data reported by Hogan et al. ${ }^{18}$ were in disagrement with those obtained by others since they did not detect significance for a history of sunburn. In the present study, although sunburn was not a significant risk factor per se, it acquired particular relevance when the skin was of type III.

Table 4. Controlled studies of risk factors for basal cell carcinoma.

\begin{tabular}{|c|c|c|c|c|}
\hline $\begin{array}{c}\text { Risk } \\
\text { factors }\end{array}$ & $\begin{array}{l}\text { Gellin } \\
\text { et al. } \\
1965^{*}\end{array}$ & $\begin{array}{l}\text { Vitaljano } \\
\text { \& Urbach } \\
1980^{* *}\end{array}$ & $\begin{array}{c}\text { Green } \\
\& \text { Battlstutta } \\
1990^{* *}\end{array}$ & $\begin{array}{l}\text { Hogan } \\
\text { et al. } \\
1989^{* *}\end{array}$ \\
\hline Actin changes & $\#$ & \# & $s$ & $\#$ \\
\hline Agricultural activity & $\#$ & $\#$ & \# & $\mathbf{S}$ \\
\hline Light skin & $\$$ & S & S & $S$ \\
\hline Freckles in childhood & $\#$ & $\#$ & $\#$ & $S$ \\
\hline Exposure to the sun & $S$ & $\mathbf{S}$ & $\mathrm{s}$ & NS \\
\hline Light hair & $\mathbf{S}$ & $\#$ & $S$ & $s$ \\
\hline Sunburn & $\#$ & \# & NS & $\mathrm{S}$ \\
\hline Family hlstory of skin cancer & NS & \# & $\#$ & $S$ \\
\hline
\end{tabular}

*Nonadjusted data

** Adjusted data; S, significant; NS, nonsignificant; \# not studied 
Risk Factors that Differed Significantly between Cases and Controls and that were Nonsignificant when submitted to Multiple Conditional Logistic Regression Analysis

Most of the time, the other suspected risk factors studied here have been quoted out in the literature as being related to the onset of BCC. Multiple conditional logistic regression analysis did not show significance for residence in the rural zone, light hair color, patient awareness of the cancerigenous effect of the sun on the skin, family history of skin cancer, light eye color, intense exposure to the sun or presence of freckles in childhood (Table 2). Each of these factors is discussed below.

\section{Residence in the Rural Zone}

Residence in the rural zone has not been studied as a risk factor in the international literature but was studied here because Brazil is still a largelly agriculturai country.

In the Brazilian literature, only Prado ${ }^{29}$ studied the origin of his BCC patients and reported that $64 \%$ were from the rural zone as opposed to $36 \%$ from the urban zone. The author commented about these results suggesting that "..it is somehow justifiable since field workers, in addition to being exposed to the sun for longer periods of time in their work, wear minimal clothing for protection."

In the present study, $59.1 \%$ of patients reported present or previous residence in the rural zone. In the control group, $41.9 \%$ of subjects also lived or had lived in the rurat zone. Multiple conditional logistic regression analysis showed that the risk of this factor was quite close to 1.0 , which is nonsignificant. Thus, in the present study, living in the rural zone wasnot by it self alone a specific risk for $\mathrm{BCC}$. This because living in the rural zone does not necessarily mean constant or obligatory exposure to the sun.

\section{Light Hair Color}

No one reports about the evaluation of light hair color as a risk factor in the Brazilian literature were found. However, significance for light hair color as a risk factor has been reported in the international literature ${ }^{\mathrm{I}, 15,18}$. According to the data of the present study, light hair color was nonsignificant by multiple conditional logistic regression analysis, with an odds ratio of 1.16 .
Thus, the results of the present study differ from those reported in the literature. What is the reason for this discrepancy? Let us consider, for example, the study by Hogan et al. ${ }^{18}$ who used a statistical analysis similar to that adopted in the present study. They worked with $538 \mathrm{BCC}$ cases, i.e, practically twice the population of the present study (259 cases) and they detected significance $(\mathrm{p}<0.05)$ for an odds ratio of 1.16 , with a standard error of 0.064 . Could our result be different if its series were increased? This may indeed occur, but the sample for this research project were they to be evaluated under the same conditions, would have to contain about $3,000 \mathrm{BCC}$ cases. And even if it became significant, as in the study by Hogan et al. ${ }^{18}$, this would be a risk factor of lower importance than that of the significant risk factors detected in the present study. Another possibility is that the sample studied by Hogan et al. ${ }^{18}$ was strongly marked by the presence of a particular ethnic group. Indeed, these investigators studied a population of strongly Irish, Scottish and Weish origin that had emigrated to Canada. This population presented a $38.5 \%$ rate of light hair in $\mathrm{BCC}$ cases and of $30.4 \%$ in their controls, as opposed to the respective values of $18.9 \%$ and $10.0 \%$ obtained in the present study.

\section{Patient Awareness of the Relationship between Sun and Skin Cancer}

Despite the information broadcast by the media about the harmful effects of the sun on the skin, no attempt has been made in the international or Brazilian literature to evaluate whether the lack of this information may represent a risk for skin cancer. When the cases here studied were evaluated, the estimated odds ratio was 1.24 , also a nonsignificant value.

This fact should not be considered surprising since the availability of this type of information to the public is very recent and may not yet have influenced the results. However, the statistical method used by the present authors is not the most appropriate one for detecting the change of habits in a given population. Furthermore, the objective of the methodology was not to study all the variables that interfere with the acquisition of this information on the part of the population. The continuation of such informative campaigns should be stimulated since it may contribute to reducing the incidence of skin cancer. 


\section{Family History of Skin Cancer}

No Brazilian studies on this risk were found factor. Hogan et al. ${ }^{18}$ showed that a family history of skin cancer was a significant risk factor for BCC, with an odds ratio of 1.22 . In a previous study, Macdonald ${ }^{2.3}$ demonstrated that individuals with a family history of skin cancer develop skin cancer at an earlier age than individuals with no such family history.

In view of these previous data, it was surprising to find that, in the patients, studied in the present study, no family history of skin cancer did not maintained significance when submitted to multiple conditional logistic regression analysis, with an odds ratio of 1.25 . It can be seen that the relative risk detected by the present authors was similar to that reported by Hogan et al. ${ }^{18}$. Here also we should emphasize the earlier discussion of sample size.

However, Gellin et al. ${ }^{11}$, in a controlled study of factors associated with BCC, also found no significance for family history of skin cancer. The authors proposed that this may have been due to several factors: 1) the older group of patients may not have remembered details about their parents; 2) different living conditions between patients and ancestors in terms of solar exposure, geographical location, occupation etc. The authors themselves admitted that the major reason for not considering this result as definitive was that in their study only $1.7 \%$ of patients stated that somebody in their family had skin cancer, a lower value than the probability of a person living in the State of New York (USA) developing skin cancer $(3 \%)$.

The present study, in which family predisposition could not be demonstrated as a risk factor, the impression created that this type of information was not available to the population studied, not only because of their low cultural level, but also because of the large number of migrants who, in most cases, had been separated from their relatives for several years. This fact may explain the nonsignificance of this variable in our series.

\section{Light Eyes}

Brazilian authors have not studied this suspected risk factor. Hogan et al ${ }^{18}$ detected no statistical significance for light eye color, whereas Gellin et al. ${ }^{11}$ did, but using a different type of statistical analysis (chi-square test). In our cases in the present study, similarly to those studied by Hogan et al, ${ }^{18}$, light eye color was nonsignificant as a risk factor, with an odds ratio of 1.3. Comparison with divergent data in the international literature ${ }^{11}$ is rendered useless by virtue of the variety of statistical methods used.

\section{Intense Exposure to the Sun.}

Brazilian authors have not conducted analytical or controlled studies of this variable. Gellin et al. ${ }^{11}$ reported significance for BCC patients who had been exposed to the sun for several hours each day. Vitaliano and $\mathrm{Urbach}^{34}$ detected a significant odds ratio for $\mathrm{BCC}$ in patients with intense solar exposure using multiple conditional logistic regression analysis; this actually occurred also when intense exposure to the sun occurred in individuals with other factors habitually considered to be low risk (dark skin, easy tanning and age of less than 50 years). Hogan et al. ${ }^{18}$ did not detect significance for this factor when using muitiple conditional logistic regression analysis. The present study fully agrees with that of Hogan et al. ${ }^{18}$.

A possible source of controversy is the definition of intense exposure to the sun. In the study by Hogan et al. ${ }^{18}$, an effort was made to quantify this variable and intense exposure was defined as outdoor activity for at least six hours a day. This includes occupations ranging from rural worker to street vendor. However, in the results of their study, $\mathrm{BCC}$ was much more common among rural workers than among other individuals working outdoors, probably because of the greater difficulty of the former in protecting themselves from solar radiation.

In the present study, this risk factor has not been quantified, not always differentiated by type of work (outdoors or indoors) or by number of hours of exposure. Patients and controls were only asked whether their life exposure to the sun had been "mild, moderate or intense". Furthermore, this information was not cross-check against type of professional activity (street vendor, rural worker etc.) or leisure activity.

Thus, the type of data collection in the various studies may perhaps account for the divergences between the results. 


\section{Freckles in Childhood}

The appearance of freckles in childhood was the most important risk factor for BCC in the study by Hogan et al. ${ }^{18}$. Other investigators ${ }^{3,8}$, however quote out freckles in childhood as a significant risk factor only for malignant melanoma of the skin.

The present results using multiple conditional logistic regression analysis, with an odds ratio of 1.5 , did not indicate significance. In addition to the possible problem of a small sample size, freckles, like sunburns, result from acute and intense exposure to the sun. Thus, our results may be in agreement with those of the literature, which includes freckles among the risk factors for malignant melanoma.

\section{Significant Risk Factors in the Multiple Conditional Logistic Regression Model}

The risk factors studied, which permitted the construct the final multiple conditional logistic regression model were: agricultural activity, skin changes attributable to solar radiation, and skin type (Table 3).

\section{Skin Type}

Light skin has always been quoted out as a risk factor for the development of skin cancer. However, more rigorous studies could only be conducted when two preliminary points were established: (a) a more precise definition of what "light skin" is, which was given by Fitzpatrick ${ }^{10}$ when he proposed his skin classification (phototypes) varying from type I to type VI and which is now universally accepted; (b) the organization of control groups for appropriate statistical evaluation.

The studies by Gellin et al. ${ }^{11}$ demonstrated that light skin was the most important risk factor for BCC in the city of New York, which has a heterogeneous population. In contrast, Vitaliano and $\mathrm{Urbach}^{34}$, when listing suspected risk factors - level of exposure to the sun, ability to tan, age, sex, and light skin - found the least risk for the last variable. Green and Battistutta ${ }^{15}$, in Australia, found light skin to be the most important risk factor, stating that "...the great problem of patients with non-melanoma skin cancer was that of belonging to a group of persons who have little pigment to protect them from an environment with high levels of ultraviolet radiation." Hogan et al. ${ }^{18}$ also detected significance for light skin.

When the classification of Fitzpatrick ${ }^{10}$, as conceived by him, was applied in this present study, a great difficulty had to be overcome in order that, the importance of the light skin factor could be evaluated. This was because skin III, which involved the largest number of BCC cases $(62.2 \%)$ was also the most numerous group among the controls $(57.1 \%)$. Type III could not be excluded series of the present study because the sample would then be extremely reduced and would not permit appropriate statistical analysis. However, analysis became viable when value has given to the information provided by the patients themselves about the previous occurrence of sunburns. On the basis of this information, it became prossible to characterize as at risk type III/with a history of previous sunburn, placing it alongside with types I and II, and as not at risk type III/without a history of sunburn, grouping it side by side with types IV and V.

Indeed, we confirmed statistically that the results obtained for types I and II and for type III/with a history of sunburn were statistically confirmed as being significantly different from type III/without a history of sunburn and from types IV and V.

This means that light skins of type I and II can be included among the risk factors and, conversely, skins of types IV, V, and VI (the last, Black skin) can be considered to be better protected. In contrast, type III skin will behave differently according to the presence or absence of burns resulting from exposure to the sun: in the presence of burns the patient will be part of the risk group, but not in the absence of burns. Thus, it could be included light skin in the Iogistic model of disease together with agricultural activity and actinic skin alterations. This conclusion, reached on the basis of the results of the process of analysis, should be discussed from a biological viewpoint, since the suspected risk factor (a history of sunburn) per se did not prove by the method utilized to be significant. However, this type of approach is not within the scope of the present study.

\section{Agricultural Activity}

Non-melanoma skin cancer has been associated with agricultural activity in England ${ }^{1}$ and in the $\mathrm{USA}^{5}$, but not in Sweden ${ }^{34}$ or Finland ${ }^{22}$. In 
Canada, Hogan et al. ${ }^{18}$ were the first specifically to associate BCC with agricultural activity.

Brazilian authors $2,4,12,27,28,29,31$ who study $B C C$ have quoted rural activity as one of the major factors in the development of the disease. These studies were not controlled but their results would probably continue to be significant even if they had been.

In the present study, agricultural activity has been identified as a more significant relative risk factor for BCC. As demonstrated earlier, it should be remembered that simply residing in the rural zone did not represent a risk factor when the $\mathrm{BCC}$ group was compared to the control group. The presence of work activity exposed to sunlight (rural workers) was needed for a statistically significant difference in risk to be established.

\section{Skin Alterations Attributable to Solar Radiation}

In the present study, we emphasized the presence of solar keratosis of the face, lentiginosis on the back of the hands, facial telangiectasia and neck elastosis as markers of sunlight-induced degeneration has been emphasized. It should be remembered that degeneration has been counsidered to be a suspected risk factor when at least three of these alterations were detected.

Marks et al..$^{25}$ and Goodman et al. ${ }^{13}$ detected a higher frequency of non-melanoma skin cancer in persons with solar keratosis and vice versa. Holman et al. ${ }^{19}$, in a study in a community of the Australian West, detected in solar keratosis $17 \%$ of men and $8 \%$ of women below 40 years by age. These investigators stated that an increasing number of young people are being seen with signs of changes provoked by solar radiation and consequently with skin cancer. Green et al. ${ }^{15}$ pointed out a greater prevalence of BCC among those who work in the sun and who develop solar keratosis. When they evaluated other solar alterations (lentiginosis, telangiectasia and elastosis), they also detected a significant relationship between them and BCC.

Brazilian investigators have not discussed this risk factor.

In the present study it has been confirmed that skin degeneration-measured on the basis of actinic changes - is an important risk factor per se. Thus, actinic alterations are part of the final model, where they appear as the risk factor skin alterations attributable to solar radiation. Actinic skin alterations, which are clinically observable, represent the effects of solar exposure of the cumulative type and this cumulative effect is the major factor causing non-melanoma skin cancer.

\section{Multiple Conditional Logistic Regression Model}

Three factors were significant by multiple conditional logistic regression analysis: light skin, agricultural activity, and skin alterations at tributable to solar radiation. Each one proved to be significant per se and they have been included in the logarithmic equation that expresses the logistic disease model (BCC):

$$
1,5938 \cdot x_{1}+1,6041 \cdot x_{2}+1,0208 \cdot x_{3}
$$

where $x_{1}$ is agricultural activity, $x_{2}$ actinic skin alterations and $x_{3}$ type of skin.

It should be kept in mind, however, that when the value of $x_{1}, x_{2}, x_{3}$ is equal to zero (absence of a risk factor) in the equation, the corresponding term is annulled, reducing the probability of occurrence of the disease. Conversely, when each of the factors is present (value one), the terms of the equation are conserved, representing an increased probability and indicating a high risk of the occurrence of BCC.

Thus, $\mathrm{BCC}$ is of multifactorial origin. The relative risk, individualized for each of the factors, that it was possible to identify in the present study, was high. When risk factors are associated in the same individual $\left(x_{1}, x_{2}, x_{3}\right.$ equal to one), the logistic regression equation obtained indicates a high probability of future development of BCC. These identified risk factors should be taken into account both for an early diagnosis and for orientation in preventive campaigns.

\section{Reach and Limitations of the Present Study}

The present study, as mentioned, was conducted in the Sector of Surgery and Oncology of the Dermatology Clinic of "Santa Casa de S. Paulo" whose clientele is characteristically represented by lower-class people from rural areas and is mostly made up of migrants from the North and Northeast of Brazil. Thus, when preparing the protocol for the present study a survey was undertaken in accordance with the characteristics of this demand. However, with the progressive urbanization of the Brazilian population and the consequent transformation 
of the characteristics of the clientele of study, the epidemiological survey will have to be modified in the future. The same applies thing to the clientele of higher socioeconomic level seen in private offices and presenting epidemiologic characteristics differing from those of the group studied here.

Thus the limitation of the results of the present study, due to the characteristics of our population and to the type of survey performed, is recognized.

However, analysis of the final model obtained, consisting of factors that were significant for BCC (light skin, agricultural activity, actinic alterations $\}$, permits the proposition that the results should be seen as far reaching and as probably being capable of extrapolation to any type of population. Light skin is a genetic characteristic present at all socioeconomic levels. Similarly, actinic alterations of the skin are not limited to one group or another. In contrast, agricultural activity, whose importance resides in the fact that this type of work favors chronic exposure to the sun, has its counterpart in the habits of higher socioeconomic level populations, who are accustomed to prolonged leisure at the beach, by the pool, or on sports fields, and to the use of artificial tanning.

On this basis, the final model of BCC risk detected in the present study may be seen as leading to the following general conclusion: persons genetically predisposed (light skin) who expose themselves to the sun in a chronic and intense manner (outdoor work and/or leisure), have a high probability of developing $B C C$ when they start manifesting actinic alterations.

\section{References}

1. ATKIN, M.; FENNING, J.; HEADY, J.A. The mortality from cancer of the skin and lip in certain occupations. Br. J. Cancer., 3:1-16, 1949.

2. BANDIERA,D.C. Tratamento cirirgico do câncer cutâneo. In:Róxo Nobre, M.O. \& Junqueira, A.C.- Cancerologia prática. São Paulo, Fundo Editorial Procienx, 1967. p. 197-213.

3. BERAL, V.; EVANS, S.; SHAW, H. Cutaneous factors related to the risk of malignant melanoma. $\mathrm{Br} . \mathrm{J}$. Dermatol., 109:165·72, 1983.

4. BOPP, C.; BERNARDI, C.D.V.; MULLER, R.; BAKOS, L.; GERVINI, R.L.; KOSMINSKI, B.; MULLER, L.F.B.;FERREIRA, J.; GASPARRI, B.G.; FAURI, J.C.C.; PONZIO, H.A.S.; VETTORATO, E.S.; FERRAIRA, O.D. Análise interpretativa das dermatoses mais fregilentes em Porto Alegre-Rio Grande do Sul, Brasil. An. Bras. Dermatot., 48:117-32, 1973.

\section{Conclusions}

Statistical analysis of the data obtained with the protocol (chi-square test and multiple conditional logistic regression) led to the following conclusions with regard to the population studied:

1. Risk factors per se are type I and II light skin, according to Fitzpatrick's ${ }^{10}$, professional activities carried out under constant exposure to sunlight (agricultural activity), and the presence of skin changes due to chronic exposure to sunlight.

2. Type III skin according to Fitzpatrick's ${ }^{10}$ represents a risk factor only when there is a previous history of intense sunburn, whereas in the absence of such a history type III skin is no longer a risk factor.

3. The risk factors indicated could be included in the logarithmic equation that expresses the logistic disease model: $1,5938 . \mathrm{x}_{1}+$ $1,6041 \cdot x_{2}+1,0208 \cdot x_{3}$, where $x_{1}$ is agricultural activity, $x_{2}$ is actinic skin alterations, and $x_{3}$ is skin type.

4. Sunburns do not represent a risk factor, although the point made in item 2 of these conclusions is valid.

5. The other suspected risk factors not confirmed by multiple conditional logistic regression analysis were: residence in the rural zone, light eyes and hair, extent of information about the sun $x$ skin cancer relationship, a family history of skin cancer, intense exposure to the sun, and presence of freckles in childhood.
5. BURMEISTER, L.F.Cancer mortality in Iowa farmers, 1971* 1978. J. Natl. Cancer inst., 66:461-4, I981.

6. CAMPOS FILHO, N. \& FRANCO, E.L. A microcomputer program for multiple logistic regression by unconditional and conditional maximum likelihood methods, Amer. J. Epidemiol., 129:439-44, 1989.

7. CHUANG, T.; POPESCU, A,; SU, D.W.P.; CHUTE, C.G. Basal cell carcinoma: a population-based incidence study in Rochester, Minnesota. I. Am. Acad.Dermatol., 22:413-7, 1990.

8. ELWOOD, J.M,; GALLAGHER, R.P.; HILL, G.P. Pigmentation and skin reaction to sun as risk factors for cutaneous melanoma: western Canadarnelanoma study. Br. Med. J. (Clin.Res.), 228: 199-202, 1984.

9. FINN,O.A. Skin colouring in rodent ulcer with special reference to jute workers. Br. J. Dermatol., 70:218-9, 1958.

10. FITZPATRICK, T.B. The validity and practicality of sun reactive skin types I-VI.Arch. Dematol., 124:869-71,1988.

11.GELLIN, G.A.; KOPF, A.W.; GARFINKEL, L. Basal cell epithelioma: a controlled study of associated factors. Arch. Dermatol., 91:38-45, 1965. 
12. GOLCMAN, B.; FRIEDHOFER, H.; RIVITTI, E.A.; ANGER, M.;SOUZA, L.C.; GOLCMAN, R. Carcinomas basocelular e espinocelular da pele. An. Bras. Dermatol., 53:373-83, 1978.

13. GOODMAN, G.J.; MARKS, R.; SELWOOD, T.S. Nonmelanotic skin cancer and solar keratoses in Victoriaclinical studies II. Aust. J. Dermatol., 25:103-6, 1984.

14. GORDON, S. Basal cell carcinoma. Canad. J. Surg., 4:468-72, 1961 .

15. GREEN, A, \& BATTISTUTTA, D, Incidence and determinants of skin cancer in a high-risk Australian population. Int. J. Cancer, 46:356-61,1990.

16. GREEN, A.; BEARDMORE, G.; HART, V.; LESLIE, D.; MARKS,R.; STAINES, D. Skin cancer in Queensland population.J. Am. Acad. Dermatol.,19:1045-52, 1988.

17. HARVEY, I.; SHALOM, D.; MARKS, R.M. ; FRANKEL, S.J. Nonmelanoma skin cancer. Br. Med. J.,299:118-20, 1989.

18. HOGAN, D.J.; TO, T.,; GRAN, L.; WONG, D.; LANE, P.R. Risk factors for basal cell carcinoma. Int. J.Dermatol., 28:59]-4, 1989.

19. HOLMAN, C.D.J.; ARMSTRONG, B.K.; EVANS, P.R. Relation-skin of solar keratoses and history of skin cancer to objective measures of actinic skin damage. Br. J. Dermatol., 110:129-38, 1984.

20. KINNEAR, J. Degenerative changes in skin with special reference to jute workers, Br. J. Dermatol, $66: 344-9$, 1954.

21. KRICKER, A.; ENGLISH, D.R.; RANDEL, P.L.; HEENAN, P.J.; CLAY, C.D.; DELANEY, T.A.; ARMSTRONG, B.K. Skin cancer in Geraldton, Western Australia: a survey of incidence and prevalence. Med. J. Aust., 152:399-407, 1990.

22. LINDQUIST, C; ; TEPPO,L.; PULKULA, E. Occupations with low risk of lip cancer show high risk of skin cancer of head. Community Dent. Oral Epideminl.,9:247-50,1981.

23. MAcDONALD, E.J. Epidemiology of skin cancer, 1975. In: Neoplasms of the skin and malignant melanoma. Chicago, Year-book, 1976, p.27.42.

24. MACKIE, R.M. \& RYCROFT, M.J. Health and the ozone layer skin cancers may increase dramatically. Br. Med. J., 297:369-70, 1988 .

25.MARKS, R.; PONSFORD, M,W,; SELWOOD, T.S. Nonmelanotic skin cancer and solar keratoses inVictoria. Med. J. Aust., 2:619-22, 1983 .

26.MCCARTHY, W.H. \& SHAW, H.M. Skin cancer in Australia. Med. J. Aust., 150:469-70, 1989.

27. MINELLI, L. Estudo estatístico do carcinoma basocelular em Londrina, Paraná, Brasil. An. Bras.Dermatol. 62:321-5, 1987.

28. NASSER, N. Incidência de câncer de pele na região sul do Brasil. An. Bras. Dermatol, 61:69-72,1986.

29. PRADO, H. Cåncer de pele Piaú - 1964-1984. I- Carcinoma basocelular. An. Bras. Dermatol.62:143-6, 1987.

30.SCOTTO, J.; COTTON, G.; URBACH, F.; BERGER, D.; FEARS, T.Biologically, effective ultraviolet radiation: surface measurements in United States, 1974 to 1985. Science, 239; 762-4, 1988 .

31.SERRUYA, J. Incidência das dermatoses na Guanabara An. Bras. Dermatol., 49:237-44, 1974.

32.SILVERBERG, E. \& LUBERA, J.A. Cancer statistics, 1988. C.A., 38:14-5, 1988

33. URBACH,F. The biological effects of increased ultraviolet radiation: an update. Photochem.Photobiol., 50:43941, 1989.

34. VITALIANO, P.P. \& URBACH, F. The relative importance of risk factors in nonmelanoma carcinoma. Arch.Dermatol., 116;454-6, 1980.

35. WIKLUND, K. Swedish agricultural workers; a group with a decreased risk of cancer, Cancer, 51:566-8, 1983.

\section{Resumo}

Realizou-se estudo controlado para investigar quais os fatores de risco, para o desenvolvimento do carcinoma basocelular, săo significantes. Foram utilizados 259 casos de carcinoma basocelular (diagnosticados entre juiho de 1991 e julho de 1992) e 518 controles, pareados segundo sexo e idade. Submetidos os dados constantes do protocolo à análise estatistica (Qui-quadrado e Regressåo Logistica Múltipla Condicional), fol possivel obter as seguinies conclusōes na populaçāo estudada: 1 - Representam fatores de risco, por si só: - as peles claras de tipo le li de Fitzpatrick; - a atividade profissional desenvolvida sob exposição constante à (uz solar (atividade agropecuária)i - a presença de afteraçঠes cutâneas decorrentes da exposiçāo crónica a radiaçāo solar, 2 - A pele do tipo III, na classificaçāo de Fitzpatrick, representa fator de risco somente quando há história anterior de quelmaduras solares intensas; já em ausencia destas queimaduras anteriores, a pelo do tipo III passa para o grupo de nåo-risco. 3 - Os fatores de risco assinalados puderam ser incluidos na equação logaritimica que expressa o Modelo Logistico de Probabilidade de Doença: 1,6041, $x_{1}+1,5938, x_{2}+1,0208, x_{3}$, onde $x_{1}$ é a atividade agropecuária, $x_{2}$ săo as alteraçరes actínicas de pele e $x_{3}$ o tipo de pele. 4 - Queimaduras solares nāo representam fator de risco, embora seja válida a ressalva feita no item 2, destas conclusōes. 5 . Os outros fatores suspeitos de risco e nāo contimados pela Análise de Regressāo Logística Mültipla Condicional foram; residêncla em área rural, olhos e cabelos claros, nivel de informaçāo sobre a relaçāo sol $X$ câncer do pele, história familiar de câncer do pele, exposição solar intensa e aparecimento de efélides na infáncia. 